\title{
GINÁSIO ESTADUAL DE PILAR DO SUL: UM OLHAR SOBRE O USO DOS ESPAÇOS ESCOLARES (1959 -1976)
}

\author{
Adriana Aparecida Alves da Silva \\ xx.dri@bol.com.br \\ José Roberto Garcia \\ jrgaciajr@hotmail.com \\ Wilson Sandano \\ wilson.sandano@prof.uniso.br \\ Universidade de Sorocaba - UNISO
}

\section{RESUMO}

Os resultados apresentados neste artigo fazem parte da pesquisa em andamento que investiga o campo escolar de Pilar do Sul - SP. Em meados da década de 50, o campo escolar de Pilar do Sul era constituído por três escolas, e este trabalho busca compreender a história de uma delas, o Ginásio Estadual de Pilar do Sul, analisando a arquitetura e os usos dos espaços escolares no período de 1959, ano de início de funcionamento do ginásio, a 1976, momento em que o ginásio é redefinido como escola de primeiro grau. Foram utilizadas fontes escritas, orais e iconográficas. A análise evidenciou, entre outros aspectos, que havia uma preocupação com a questão da salubridade e espaços específicos para artes manuais, apresentações artísticas e laboratório de ciências. A existência e a boa localização desses espaços nos revelam a importância de práticas escolares valorizando a formação integral pautada no civismo e na racionalidade científica. No entanto, os usos desses espaços não aconteciam plenamente, pois não havia materiais científicos para o laboratório ou livros e outros materiais, nem mobiliário para o seu pleno funcionamento. Outro aspecto é a posição do gabinete do diretor, centralizado, permitindo a constante vigilância e a disciplina rígida.

Palavras chaves: Arquitetura escolar. Ginásio. Pilar do Sul.

\section{GINÁSIO ESTADUAL DE PILAR DO SUL: A LOOK ON THE USE OF SCHOOL PLACES (1959 -1976)}

\section{ABSTRACT}

The results presented in this article are part of the ongoing research that investigates the school field in Pilar do Sul - SP. In the mid-1950, the school field in Pilar do Sul consisted of three schools, and this work seeks to understand the history of one of them, the Pilar do Sul State Gymnasium (Ginásio Estadual de Pilar do Sul), analyzing the architecture and uses of school spaces from 1959, when it started its works, to 1976, when the Gymnasium is redefined as Elementary School. We used written, oral and iconographic sources. The analysis showed, among other things, that there was a concern with the issues of health and specific areas for arts and crafts, performing arts and science lab. The existence and good location of those spaces reveal the importance of school practices enhancing the comprehensive training in civics and guided scientific rationality. However the uses of those spaces did not take place fully, because there were no scientific materials for the lab, or books and other materials, nor furniture for their complete operation. Another aspect is the position of the principal's office, allowing centralized constant vigilance and strict discipline. 
Keywords: School Architecture. Gymnasium. Pilar do Sul.

\section{Introdução}

A arquitetura escolar e o espaço escolar são portadores de significados múltiplos que exigem do pesquisador um olhar aguçado, sensível para poder compreender as várias dimensões implícitas. A leitura dessas diferentes dimensões torna o estudo da arquitetura e espaço escolar eixo de análise e compreensão histórica das instituições escolares.

Compreendemos a arquitetura e o espaço escolar como um dos elementos que compõem a "cultura escolar". A noção de cultura escolar será interpretada como um conjunto dos aspectos institucionalizados que caracterizam a escola. De acordo com Frago (1998) cultura escolar pode ser compreendida:

Práticas de conduta, modos de vida, hábitos e ritos, a história cotidiana do fazer escolar - objetivos materiais - função, uso, distribuição no espaço, materialidade física, simbologia, introdução, transformação, desaparecimento... e modos de pensar, bem como significados e idéias compartilhadas (FRAGO, 1998, s/p).

Segundo Frago deve-se "considera o espaço escolar como um espaço segmentado no qual distingue, em primeiro lugar, as zonas edificadas das não edificadas e, dentro de ambas as atribuídas a uma ou a mais função ou tarefa..." (FRAGO, 2005, p.19).

Este artigo analisa a arquitetura e os usos dos espaços escolares do Ginásio Estadual de Pilar do Sul no período entre 1959, ano de inicio do funcionamento das atividades do ginásio, a 1976, momento que o Ginásio Estadual de Pilar do Sul foi redefinido como escola de primeiro grau, face ao disposto na Lei 5692/71.

A década de 1950 marca o início do processo de urbanização de Pilar do Sul. Analisar a história da cidade de Pilar do Sul é tentar compreender uma lógica peculiar com modos de viver e pensar marcados pela oralidade e por um "tempo da natureza" (TOMPSON, 1998 p. 268) e não do relógio, um viver que se desenrola pelas necessidades dos afazeres do cotidiano. Nesse contexto no final da década 50, foi fundado o Ginásio Estadual de Pilar do Sul.

Para compreender uma das facetas desta historia utilizamos diversas fontes (escritas, orais e iconográficas) considerando a especificidade de cada documento, seguindo orientações de Le Goff (1990), que rompe com a idéia de prova isolada e apresenta o documento como produto de uma sociedade que o fabricou segundo suas relações de forças. Dentre as fontes utilizadas é importante destacar as fontes orais e iconográficas.

Em relação às fontes iconográficas, utilizamos plantas e fotos que foram considerados como suportes de experiências e memórias, pois:

as imagens não falam por si mesmas, interpretar seus significados, atribuir-lhe valor estético, compreender suas representações sociais, descrever seus espaços de sociabilidades comportamentos subjacente, identificar seus personagens, tudo isso obriga aos estudiosos das imagens do passado o recurso a outras fontes de informação. Dentre estas, o relato oral, quando possível, é o que mais se acomoda às tramas da memória (MAUAD, 2009, p.03). 
O entrelaçamento das diversas fontes, entre elas, a fonte oral e as imagens permitiu a interpretação das memórias e suas imagens.

Fruto deste constante diálogo e confronto com as fontes, apresentaremos de forma breve e resumida o surgimento do interesse de construir um prédio especifico para escola no Brasil, um pouco do emaranhado que compõe a história da fundação do Ginásio Estadual de Pilar do Sul em seguida uma breve análise sobre a arquitetura e os usos dos espaços escolares do Ginásio Estadual de Pilar do Sul.

\section{Arquitetura Escolar}

Um dos elementos chaves na configuração da cultura escolar de uma determinada instituição educativa, juntamente com a distribuição e os usos do tempo, os discursos, as práticas, normas entre outros elementos, é a arquitetura escolar e o usos dos espaços.

Segundo Frago (1995, p. 69) o espaço escolar não é, pois, um "contenedor", nem um "cenário", mas sim "uma espécie de discurso que institui em sua materialidade um sistema de valores". É como a cultura escolar da qual faz parte, uma forma silenciosa de ensino e qualquer mudança em sua disposição, modifica sua natureza cultural e educativa.

Desta forma, podemos enfatizar o quanto foi significativa e importante para a organização do ensino a adoção, no final do século XIX e início do XX, dos Grupos Escolares que trouxe consigo, uma nova forma escolar que construía e se impunha sobre as escolas isoladas.

Segundo Souza (1999) o Grupo Escolar foi implantado no Estado de São Paulo no interior do projeto republicano e representava inovações na organização administrativa, pedagógicas e arquitetônicas concebidas na "racionalidade cientifica" e na "divisão do trabalho". Nas palavras da autora:

Esta modalidade de escola primária foi implantada, pela primeira vez no Brasil, no estado de São Paulo em 1893 e correspondeu, na época, a um novo modelo de organização administrativo-pedagógico da escola primaria com base na graduação escolar - classificação dos alunos por grau de adiantamento - no estabelecimento de programas de ensino e da jornada de aula em um mesmo edifício-escola para atender a um número de crianças, na divisão do trabalho e em critérios de racionalização, uniformidade e padronização do ensino. (SOUZA, 1999, p.104).

Com a implantação gradual dos Grupos Escolares iniciou-se a construção de edifícios próprios para o funcionamento de escolas públicas que substituíram as escolas isoladas que funcionavam em precárias acomodações, fossem instaladas na casa do próprio professor, improvisadas em paróquias ou em salas alugadas em locais pouco apropriados, sem iluminação adequada, mobiliário e higiene.

No inicio da implantação dos Grupos Escolares em estados e cidades brasileiras os edifícios escolares possuíam uma arquitetura monumental e majestosa com a finalidade de enaltecer a ação do poder público e, consequentemente, o novo regime, a República.

Segundo Correa (2005) a arquitetura monumental ostentava representações sociais e políticas e o convívio com longos corredores, grande janelas, a higienização dos espaços e o destaque do prédio escola com a relação à cidade que o cercava, visava incutir a valorização estética constituída pelas luzes da República e o apreço à educação racional e científica.

Ao longo do século XX a imponência da arquitetura escolar das instituições públicas sucumbiu à falta de recursos e as políticas de construção de prédios escolares. Fundamentada nos princípios da racionalidade financeira e técnica, as políticas de 
construções de prédio, o máximo de aproveitamento do espaço e, assim, redundando em construções econômicas de traçados simples sem muita imponência. A política de expansão do sistema escolar público tornava financeiramente inviável manter o caráter monumental dos edifícios escolares públicos.

A princípio, a política de expansão da escola público no Estado de São Paulo concentrava seus esforços na escola primária, que era a grande necessidade da população, mas, em meados da metade do século XX começou a surgir o interesse pela escola secundária, que até então era uma escola direcionada a elite.

Segundo Sposito “(...) a escola secundária constituía-se no marco divisor entre educação das elites e a educação popular (... ) A 'dualidade' do sistema se definia e adquiria contornos precisos no ensino de nível médio (...)” (SPOSITO, 1984, p.11).

Em meados de 1940 havia no Estado de São Paulo apenas três escolas secundárias e, segundo Sposito, em São Paulo, essa modalidade de ensino se tornou reivindicação por parte das camadas populares da sociedade, pois, ao comporem o teor de seus projetos sociais, incorporaram, como seus, os modelos educativos que encontravam já formulados no projeto de vida das camadas sociais mais favorecidas. Tendo como objetivo o projeto de vida das camadas sociais mais favorecidas, as camadas populares começaram a reivindicar o ensino secundário. Este movimento levou ao aumento do número de escolas secundárias, que, apesar de se manter como uma escola elitista começou a serem freqüentadas pelas camadas populares.

Entre 1942 e 1961 muitas mudanças alteraram a estrutura da escola secundária. A reforma do ensino, organizada na gestão do ministro Gustavo Capanema, em 1942, reestruturou o ensino secundário. Houve um aumento no número de escolas, pois em 1940 eram apenas três ginásios no Estado e, por volta de 1970, seu número já se aproximava de quatrocentos.

Assim como o grupo escolar foi utilizado para enaltecer o poder público, a fundação de novos ginásios foi utilizada como instrumento político. Beisigel (1964), analisando a expansão da rede de escolas públicas no Estado São Paulo, afirma que as escolas foram utilizadas como moeda de troca a interesses eleitoreiros. Interesses eleitoreiros e benefícios políticos que ficavam à frente de interesses educacionais.

A ampliação de criação de escolas secundária, principalmente ginásios, fez proliferar uma cultura escolar especifica dessa modalidade que está entrelaçada com o processo de ampliação do sistema escolar. Assim como os grupos escolares sofreram alterações nos prédios escolares devido à política expansão e mudança na cultura escolar que propuseram outras organizações nos espaços escolares, o ensino secundário passou por transformações ao longo dos anos devido às diferentes políticas e mudanças na cultura escolar.

Desta forma a arquitetura escolar do ginásio, no seu processo de expansão da rede de ensino, eram construções menos suntuosas por razões econômicas e financeiras ou, muitas vezes, eleitoreiras. Os ginásios no Estado de São Paulo, muitas vezes, eram criados nas regiões que garantissem maior rendimento a interesses eleitorais, não levando em consideração a clientela, o corpo docente e principalmente a construção de um prédio adequado que atendesse as necessidades pedagógicas.

O Ginásio Estadual de Pilar do Sul teve sua criação norteada por interesses eleitoreiros, tendo os vereadores locais e os deputados estaduais como principais mediadores. Foi fundado sem possuir prédio próprio, matérias e professores qualificados para o seu funcionamento. Foi necessário que o Grupo Escolar "Padre Anchieta" cedesse o seu espaço físico para que o ginásio pudesse começar a funcionar. Os pais dos alunos do 
ginásio tiveram de arrecadar fundos para a compra dos materiais necessários ao bom funcionamento da escola.

\section{Criação do Ginásio Estadual de Pilar do Sul}

O Ginásio Estadual de Pilar do Sul começou a funcionar em 02 de março de 1959, num período de grande expansão do ensino secundário no estado de São Paulo, principalmente do ensino de $1^{\circ}$ ciclo, o ginásio, e de várias transformações no município de Pilar do Sul.

A iniciativa de criação do ginásio em Pilar do Sul partiu da Câmara de Vereadores com apoio das famílias cujos pais tinham maior escolaridade. A primeira discussão referente à criação de um ginásio estadual em Pilar do Sul ocorreu em 1957 na Câmara Municipal.

Na sessão da Câmara Municipal de Pilar do Sul, ocorrida em 17 de junho de 1957, o vereador Julio da Silveira Diniz requereu que fosse enviado, ao deputado Abreu Sodré, ofício com os agradecimentos do município, pela apresentação do projeto de lei $n^{\circ}$. 408, de 1957, que dispunha sobre a criação do Ginásio do Estado em Pilar do Sul, e solicitação para fosse solicitada urgência na tramitação do projeto.

Com a aprovação do requerimento, foi enviado ao deputado o oficio $n^{\circ}$. 24/57 que, além dos agradecimentos e pedido de urgência na tramitação do referido projeto de lei, informava que a municipalidade ofereceria terreno para construção do prédio para a instalação do Ginásio do Estado na cidade.

O projeto de lei $\mathrm{n}^{\circ}$. 408, publicado no Diário Oficial de 23 de maio de 1957, dispunha sobre a criação de um ginásio do Estado em Pilar do Sul, pois

o desenvolvimento econômico de Pilar do Sul indica que se trata de uma comuna merecedora de especiais atenções do poder público estadual. Um dos aspectos que deve preocupar o Estado e o ensino médio, pela localização, na cidade de um Ginásio, que permita aos egressos do ensino primário a continuação de seus estudos (DIÁRIO OFCIAL, 23 DE MAIO DE 1957).

O projeto de lei 408/1957, após os trâmites legais e sua aprovação pela Assembléia Legislativa do Estado de São Paulo, transformou-se na Lei $n^{\circ}$ 4791, publicado no Diário Oficial do estado de 14 de agosto de 1958.

Após a aprovação do projeto e sansão do governador, a Câmara Municipal, envia ao governo do estado o ofício $n^{\circ}$ 43/58 (10 de novembro de 1958), agradecendo a criação do ginásio e a autorização para a construção do prédio, acontecimentos que, segundo a Câmara Municipal, “... veio encher de alegria o coração dos pilarenses, alegria que os nossos eleitores externaram em três de outubro, com retumbante vitória aqui do candidato situacionista, Professor Carvalho Pinto".

No final de 1958, após autorização do Governador Jânio Quadros, em ofício da Presidência da Câmara, o Secretário de Educação designou o professor Araldo Alexandre de Almeida Souza para instalar o ginásio.

O ginásio foi instalado em 02 de março de 1959, sem verba do governo estadual para aquisição do material necessário para o seu funcionamento. Os pais que tinham filhos que iriam ingressar no Ginásio Estadual e Pilar do Sul mobilizaram-se e angariaram fundos para a aquisição dos materiais necessários aos cursos de Ciências e Trabalhos Manuais. Segundo registros encontrados nas Atas das Reuniões de Pais e Mestres do Ginásio, as 
famílias que tinham filhos que ingressariam no ginásio naquele ano teriam arrecado cerca de 80 mil cruzeiros.

De acordo com a Resolução $\mathrm{n}^{\circ} 7 / 58$, a Prefeitura Municipal recebeu autorização para doar ao Instituto de Previdência do Estado um lote de terreno para construção do prédio do primeiro Ginásio Estadual de Pilar do Sul.

Em 19 de agosto de 1958, compareceram diante do tabelião Hildeberto Vieira de Mello, do $19^{\circ}$ Tabelião de Notas da cidade de São Paulo, a Prefeitura Municipal de Pilar do Sul, representada pelo seu Prefeito Pedro Batista, e o Instituto de Previdência do Estado de São Paulo, representado pelo Dr. Oswaldo Pinheiro Dória, para lavrar a escritura de doação do imóvel municipal ao Instituto de Previdência do Estado de São Paulo.

Enquanto não começassem e concluíssem as obras do prédio destinado ao Ginásio Estadual de Pilar do Sul, a instituição seria instalada no prédio onde funcionava o Grupo Escolar "Padre Anchieta".

\section{O funcionamento do Ginásio Estadual de Pilar do Sul, no prédio do Grupo Escolar "Padre Anchieta".}

O Ginásio Estadual de Pilar do Sul e o Grupo Escolar "Padre Anchieta" dividiram o prédio por três anos, até setembro de 1961, quando foi inaugurado e transferido o Ginásio do Estado de Pilar do Sul, para o seu próprio prédio.

O Inspetor Escolar, Oswaldo de Mello, visitou o Grupo Escolar "Padre Anchieta" no dia 19 de fevereiro de 1959 e informou ao Diretor Altamir Gonçalves que no dia $1^{\circ}$ de março o prédio do Grupo Escolar também atenderia o ginásio, recentemente criado.

Para que o prédio do Grupo Escolar pudesse comportar as atividades das duas instituições, ele foi reformado. Duas salas de aula e novas instalações sanitárias foram construídas.

O Ginásio Estadual de Pilar do Sul funcionou em duas classes de $1^{\mathrm{a}}$ série, sendo uma feminina e uma masculina, no horário de $14 \mathrm{~h} 10 \mathrm{~min}$ as $17 \mathrm{~h} 10 \mathrm{~min}$, pois o Grupo Escolar dividia o horário da manhã em dois períodos: das $7 \mathrm{~h} 45 \mathrm{~min}$ às $10 \mathrm{~h} 45 \mathrm{~min}$ e das $11 \mathrm{~h}$ às $14 \mathrm{~h}$

De acordo com a documentação consultada, 65 candidatos inscreveram-se para o exame de admissão ao Ginásio Estadual de Pilar do Sul, em 1959. O exame foi realizado no Ginásio Municipal "Marina Cintra" em Sorocaba, e, dos 65 inscritos, 62 foram aprovados.

Segundo Silvia Diniz ${ }^{1}$, quando chegou o resultado do exame de admissão, o sino da igreja badalou como estivesse anunciando uma festa e, depois, foi anunciado pelo alto falante os nomes dos aprovados em ordem alfabética. Depois do anuncio, foi uma festa no coreto da praça.

Nos anos seguintes, o ginásio ampliou o número de vagas e deixou progressivamente de compor turmas separadas por gêneros. Em 1960 funcionou com três: classes duas de $1^{\text {a }}$ série, uma feminina, uma masculina e uma $2^{\text {a }}$ série mista. Em 1961 funcionou com quatro classes: duas de $1^{\mathrm{a}}$ série, uma feminina, uma masculina, uma $2^{\mathrm{a}}$ mista e uma $3^{\text {a }}$ mista.

Em 1960 com o aumento das séries oferecidas, a $2^{\text {a }}$ série do ginásio teve que funcionar no Salão PIO X ${ }^{2}$, que ficava próximo ao prédio do Grupo Escolar. Os alunos adoravam, pois para ir ao banheiro ou no horário do recreio tinham que sair do salão e ir até o Grupo Escolar e tudo era motivo para "passear". 
Segundo Carvalho ${ }^{3}$, o Grupo Escolar e o Ginásio do Estado dividiram o prédio dentro da normalidade, sem conflitos, pois os espaços eram bem divididos. Cada diretor tinha sua própria sala e cada instituição era responsável pelas salas no período que as ocupava.

Já para Silvia Diniz, para direção tudo ocorria dentro da normalidade, sem conflitos, pois as confusões entre os alunos não chegavam ao conhecimento dos diretores. Os alunos do Ginásio eram unidos e se protegiam. Os alunos do Grupo Escolar não reclamavam, pois tinham medo de represálias dos alunos do Ginásio.

Eram comuns as brincadeiras entre os grupos de alunos. Os alunos do Ginásio gostavam de aprontar com as crianças do Grupo Escolar, deixando desenhos na lousa, colocando apelidos, atrapalhando as brincadeiras, entre outras traquinagens. Quando brincavam de corda, os alunos do Ginásio batiam à corda e os alunos do Grupo Escolar pulavam, mas sempre quem estava batendo a corda dava um jeito de derrubar quem estava pulando. (Silvia Diniz, 2006)

Segundo o Livro de Registro de Visitas de Autoridades Estaduais do Ensino, o Ginásio Estadual de Pilar do Sul, ficou instalado no prédio do Grupo Escolar Padre Anchieta mais tempo do que o previsto. A previsão de termino das obras era de um ano e demoraram dois anos e meio. Havia uma grande preocupação com o termino da obra e o prédio era símbolo do progresso e do prestigio político da cidade. Freqüentemente a obra do Ginásio Estadual de Pilar do Sul recebia visita das diversas turmas de alunos acompanhadas por professores e direção.

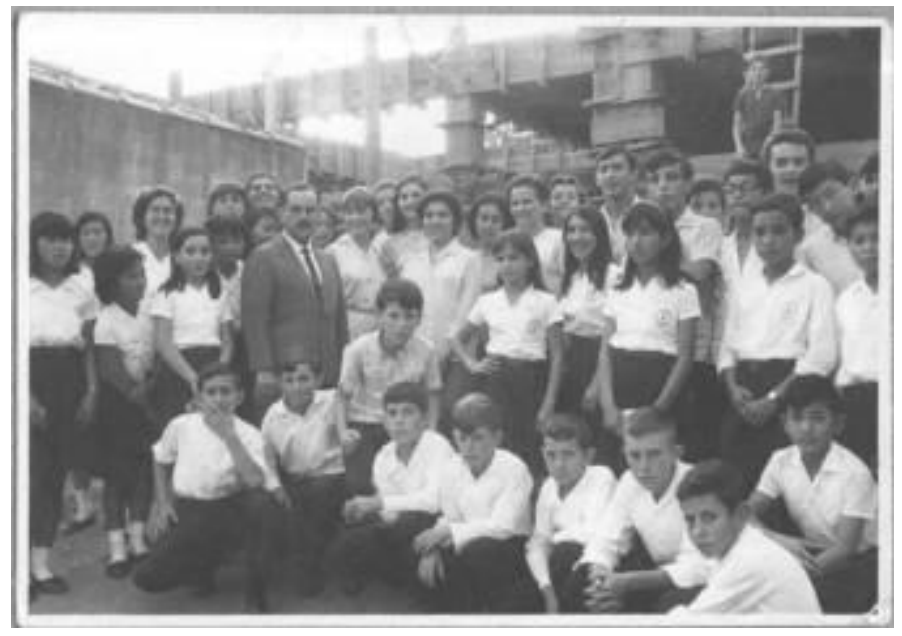

Figura 01 - Visita dos alunos, professores e direção à obra do prédio do Ginásio Estadual de Pilar do Sul. Fonte: arquivo do Ginásio Estadual de Pilar do Sul.

Em setembro de 1961 o Ginásio Estadual de Pilar do Sul foi transferido para o prédio próprio com uma grande festa de inauguração, mas as dificuldades não terminaram, pois faltavam móveis, materiais didáticos e livros. Tendo sido enviado um número reduzido de moveis e livros, para poder atender os alunos a solução foi emprestar móveis do Grupo Escolar e livros da população para formar uma pequena biblioteca. 


\section{O prédio inaugurado: novas instalações do Ginásio Estadual de Pilar do Sul}

De acordo com a Resolução $n^{\circ} 7 / 58$, a Prefeitura Municipal recebeu autorização para doar ao Instituto de Previdência do Estado um lote de terreno para construção do prédio do primeiro Ginásio Estadual de Pilar do Sul. O terreno doado pela Prefeitura Municipal tinha as seguintes características:

Forma retangular, medindo 120 metros (cento e vinte metros), para Rua: Cel. Moraes Cunha, e 120 metros (cento e vinte metros) na linha dos fundos, com 84 metros (oitenta e quatro metros) da frente aos fundos, com a área de $10.080 \mathrm{~m}$ (dez mil e oitenta metros quadrados), e confrontando do lado direito de quem da rua olha para o terreno, com a rua Major Euzébio de Moraes Cunha, do lado esquerdo e nos fundos, com terrenos pertencentes ao Patrimônio Municipal. (RESOLUÇÃO No 7/58, p. 188).

Segundo Carvalho e Oliveira ${ }^{4}$, mestres de obras e pedreiros que prestavam serviços ao Estado vieram de outras cidades para trabalhar na construção do prédio do ginásio.

A construção foi iniciada em meados de 1959 e concluída em 1961, sendo inaugurado com a presença de inúmeros políticos e autoridades da região e do Estado como os vereadores Julio Diniz E João de Carvalho, o deputado Abreu Sodré, entre outros. A população da cidade na época do início da construção estava estimada em 17.487 habitantes.

Construído próximo da praça central da cidade, na rua Cel. Moraes Cunha e com capacidade para abrigar aproximadamente 320 alunos, o prédio seguiu o modelo adotado pelos governantes da época que se utilizava de planta padronizada, aplicável a cidades com números de habitantes próximos (em Pilar do Sul, Ibiúna, Piedade e Vargem Grande Paulista foram construídos prédios com o mesmo projeto), prédios funcionais, com estilo moderno, cujas construções seriam menos onerosas e mais simples como podemos observar na fachada do prédio escolar ao fundo da primeira turma de formandos em 1962.

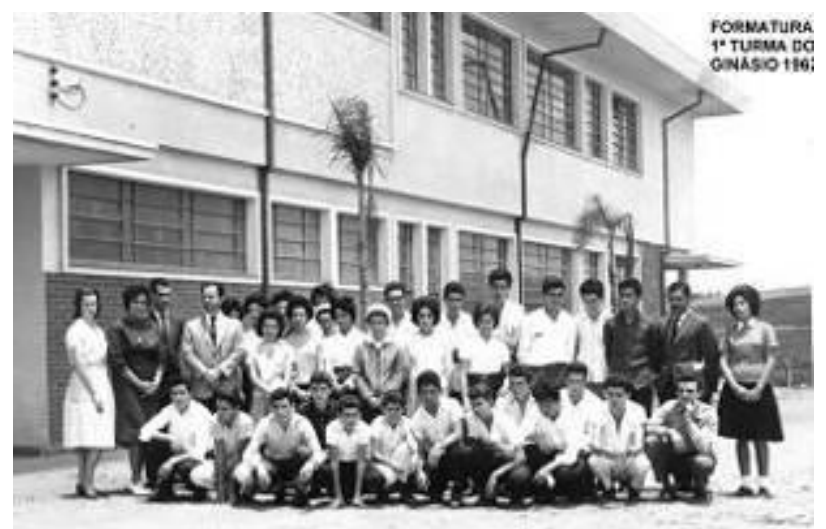

Figura 02 - Ao fundo fachada do Ginásio Estadual de Pilar do Sul e em primeiro plano a primeira turma de formandos em 1962

Fonte: Arquivo da E. E.EF. M Vereador Odilon Batista Jordão

O prédio do Ginásio Estadual de Pilar do Sul era constituído de dois pavimentos, larga área para o deslocamento dos alunos e galpão destinados à recreação, abrigo da chuva e sol, além de eventos cívicos e culturais. No térreo estão quatro salas de aulas destinadas às duas primeiras séries, quatro salas administrativas contemplando a sala dos 
professores, a secretária, a biometria, a diretoria e mais dois banheiros. Ainda no pavimento térreo está o galpão coberto, com dois banheiros de alunos, sala de trabalhos manuais e um palco com duas entradas laterais. O pavimento superior está reservado para mais quatro salas de aulas destinadas aos alunos das $3^{\mathrm{a}}$ e $4^{\mathrm{a}}$ séries, laboratório de ciências, sala para atendimento odontológico, biblioteca. A figura 03 apresenta cópia da planta original.

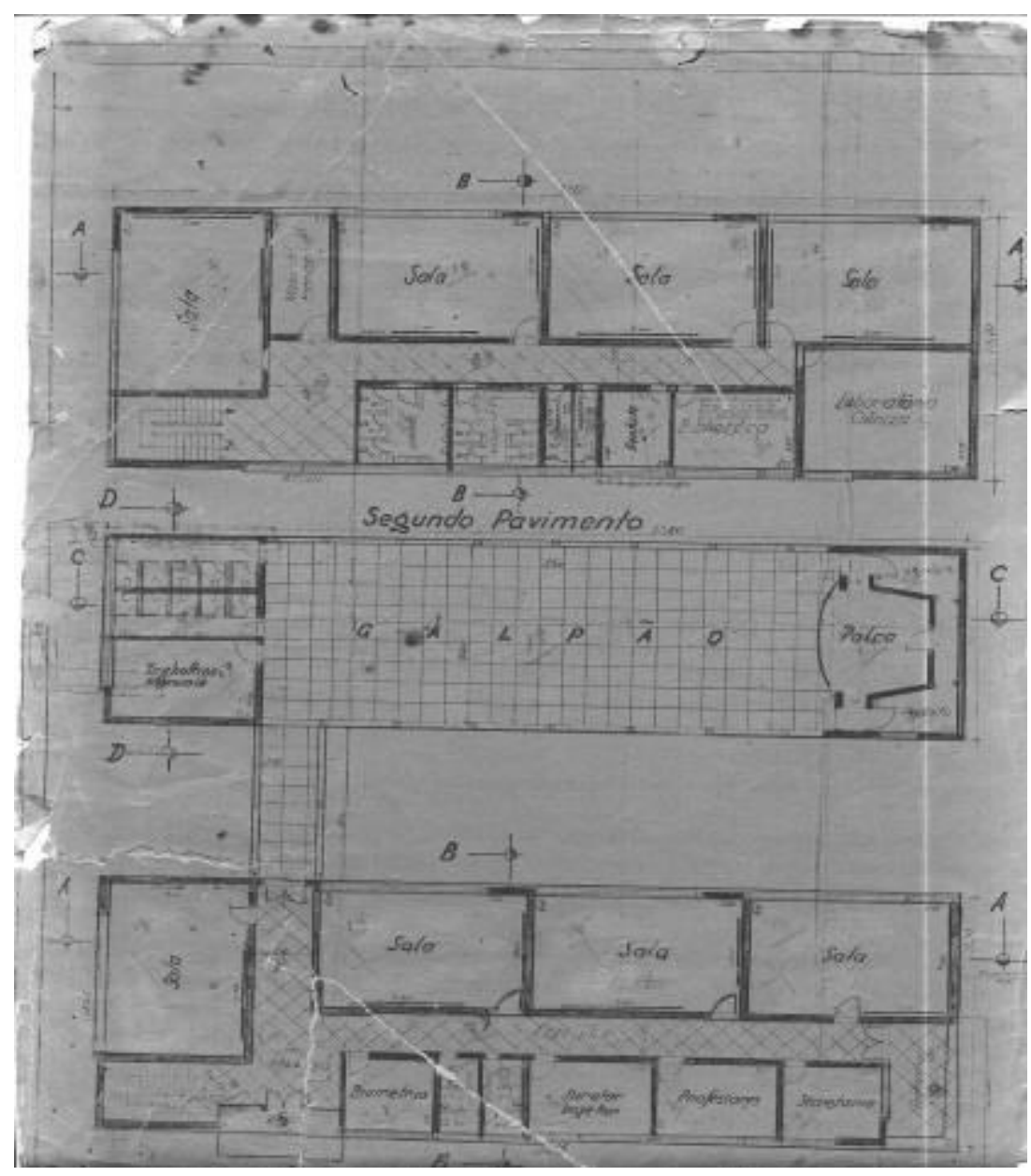

Figura 03 - cópia da planta original do Ginásio Estadual de Pilar do Sul Fonte: E. E. EF. M. Vereador Odilon Batista Jordão

$\mathrm{Na}$ figura 3.1, os cortes "CC" e "AA" orientam a construção interna do prédio, identificando a altura do revestimento das paredes, as posições das janelas e o revestimento do chão. Tetos dos dois pavimentos construídos em laje, aparecendo, ainda, as colunas de sustentação e as brocas. Em seguida observa-se a fachada principal e posterior do primeiro pavimento. $\mathrm{O}$ acesso ao pavimento térreo é feito através de escadas sugerindo que o prédio foi construído acima do nível da rua. Resquícios, talvez, do modelo adotado nas duas primeiras décadas do século $\mathrm{XX}$, as escadas nos prédios escolares poderiam sugerir $\mathrm{o}$ acesso aos "templos do saber", local onde se conseguiria superar as mazelas da vida vivida por aqueles estudantes. Apesar da escada na entrada, nota-se a inexistência de porão ou de alguma sala que abrigasse materiais para a manutenção do prédio. A fachada principal está voltada para a rua e a posterior para o interior do ginásio 


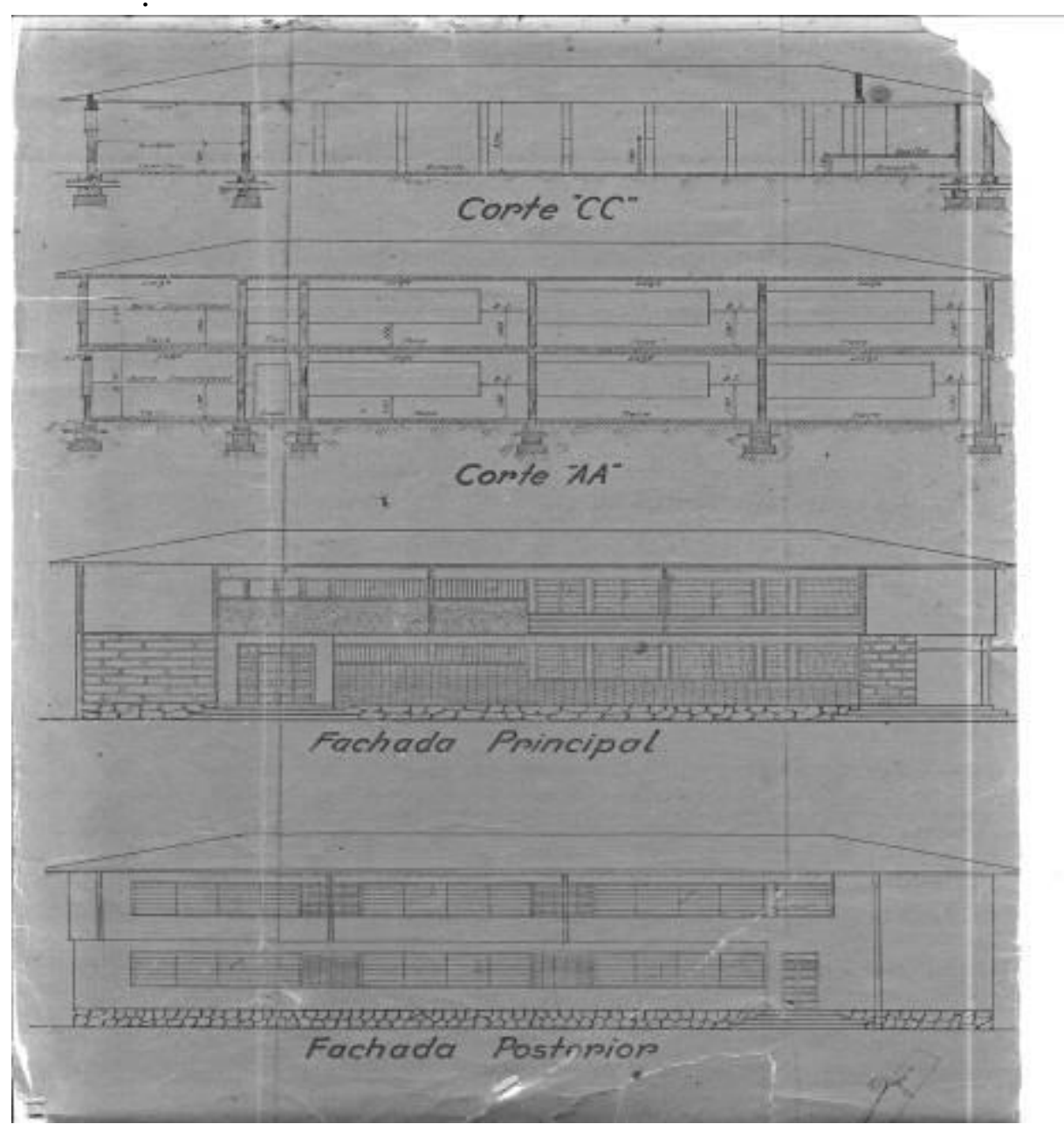

Figura 3.1 - cópia da planta original do Ginásio Estadual de Pilar do Sul. Fonte: E. E. EF. M. Vereador Odilon Batista Jordão

As salas de aulas eram bem arejadas e bem iluminadas, pois contavam com janelas amplas e distribuídas ao longo de toda a parede.

Na figura 3.2, nos cortes "DD" e "BB", existem orientações sobre os revestimentos internos das fachadas laterais, e as seguintes informações sobre a construção em metros quadrados: pavimento térreo 491.17, superior 495.52, galpão 373.00, passagem 24.80, total geral construído 1.384.49. 


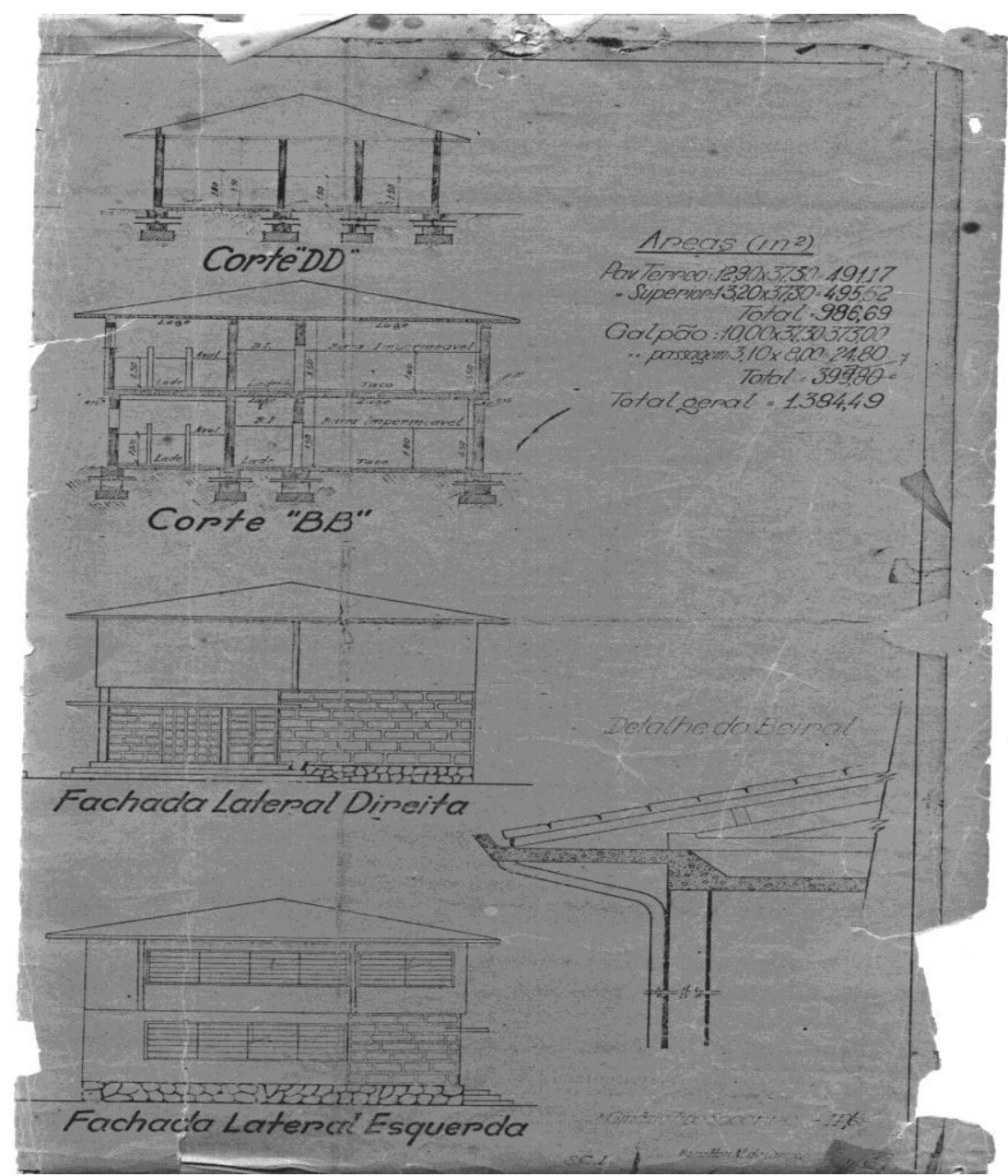

Figura 3.2 - cópia da planta original do Ginásio Estadual de Pilar do Sul Fonte: E. E. EF. M. Vereador Odilon Batista Jordão

Com precariedade de recursos e materiais, o Ginásio Estadual de Pilar do Sul começou a ocupar e fazer uso dos espaços do seu respectivo prédio e, nesse processo, o prédio começou a se constituir como espaço escolar.

\section{O prédio do Ginásio Estadual de Pilar do Sul: distribuição e usos dos espaços}

Segundo Frago (2005) a disposição física dos espaços destinados a uma finalidade ou função determinada reflete tanto sua importância como a concepção que se tem sobre a natureza, o papel e as tarefas destinadas a tal função. A localização da biblioteca, laboratórios, sala dos professores, gabinete da direção, ou qualquer outro espaço escolar refletem as diferentes concepções que se tem sobre sua natureza, papel e funções. A inexistência de um espaço pode indicar tanto o desnecessário de sua existência, como a tentativa de minimizar, reduzir a função. 
Quanto à questão da acessibilidade importa conhecer se é direta, ou indireta, ou seja, se há espaço intermediário para chegar à direção, entradas diferentes para alunos e demais pessoas.

Analisando a "planta baixa" do Ginásio Estadual de Pilar do Sul, podemos observar que havia duas entradas no Ginásio Estadual de Pilar do Sul uma destinada a visitantes, pais, professores e funcionários, próxima à secretária e na outra direção do corredor uma entrada destinada aos alunos. Entre essas duas entradas, encontrava-se, centralizada no corredor do piso inferior, a sala da direção.

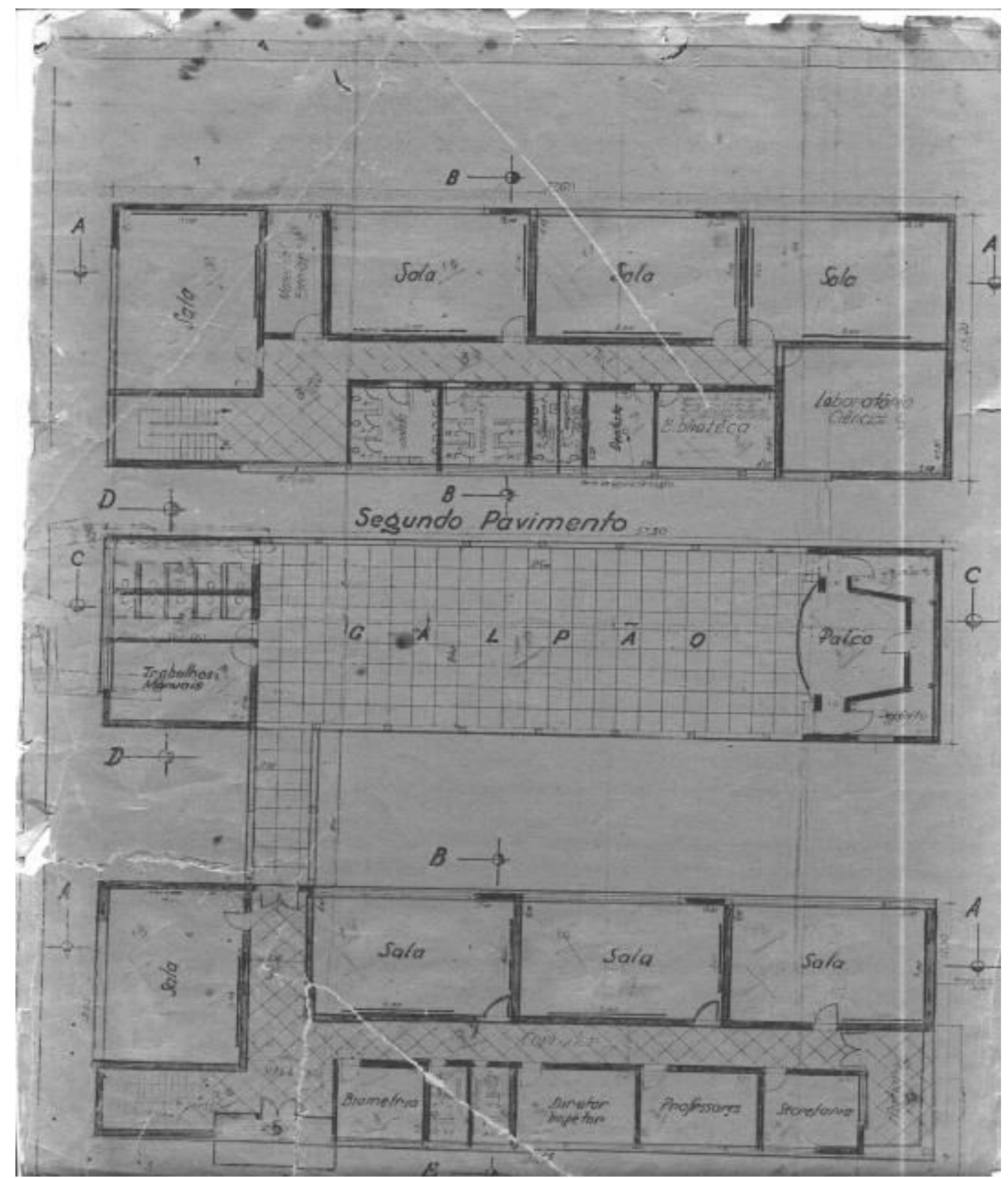

Figura 3.3 - cópia da planta baixa do Ginásio Estadual de Pilar do Sul Fonte: E. E. EF. M. Vereador Odilon Batista Jordão

A sala da direção tinha uma localização estratégica que proporcionava acompanhar o andamento das atividades escolares, pois ficava próximo da sala dos professores, 
secretária e salas de aula, ao mesmo tempo o acesso dos visitantes, pais de alunos não era direto, pois logo na entrada do corredor estava a secretaria posicionada perto da entrada.

O Ginásio Estadual de Pilar do Sul foi projetado para atender os alunos de ambos os gêneros, mas em salas separadas por gênero - na planta baixa essa preocupação fica clara, quando observamos salas em pares. Havia quatro salas de aula no piso inferior e quatro no piso superior. As salas de primeiro e segundo ano ginasial sempre ficavam no piso inferior, pois ficava próximo da direção, sala dos professores, secretária facilitando a vigilância dos alunos que estavam ingressando na instituição. Enquanto que os alunos do terceiro e quarto ano sempre ficavam no piso superior.

As salas de aulas eram arejadas respeitando os preceitos de higiene e organizadas com carteiras duplas, enfileiradas. Havia dois quadros negros, colocados um na parede anterior e outro na posterior. Era um dos espaços onde os alunos ficavam mais presos, com os movimentos limitados as suas carteiras e uma postura rígida dos professores, impondo regras que pretendiam disciplinar o corpo e a mente.

A biblioteca e o laboratório de ciências ficavam no final do corredor do piso superior. Um posicionamento que pode indicar o afastamento desses espaços do público em geral, localizado no interior do ginásio restrito aos alunos e professores. Também podemos observar o tamanho dos espaços, a biblioteca menor com espaço reduzido, enquanto o espaço do laboratório de ciências é maior. Isto nos leva a questionar sobre a importância desses espaços para o ensino e sobre o uso desses espaços.

A existência de espaço específico para biblioteca e laboratório de ciência significa a importância de certas práticas nessa modalidade de ensino e dentro de uma determinada concepção pedagógica, mas não significa que eram usados plenamente.

No Ginásio Estadual de Pilar do Sul acontecia um grande esforço para a utilização da biblioteca e laboratório de ciências, mas a falta de um acervo adequado para biblioteca e de material para o laboratório dificultava o pleno uso desses espaços.

As atas de reunião de pais e mestre registram a preocupação da falta de material para laboratório e de recursos didáticos para pleno funcionamento das atividades de ensino.

O consultório dentário e a sala de biometria não eram um detalhe ou uma simples causalidade, mas a evidência da preocupação com a formação integral desses alunos, criando hábitos saudáveis. Segundo Silvia, ex-aluna era freqüente a visita ao consultório dentário, que era um local que além de cuidar dos dentes, uma vez por ano eram ministras doses de vermíferos.

$\mathrm{Na}$ sala de biometria, ficavam os materiais de educação física, como balanças biométricas e materiais esportivos.

O prédio não possuía um espaço especifico para atividades físicas, algumas eram realizadas no pátio escolar e as esportivas, em um campo próximo ao ginásio. 


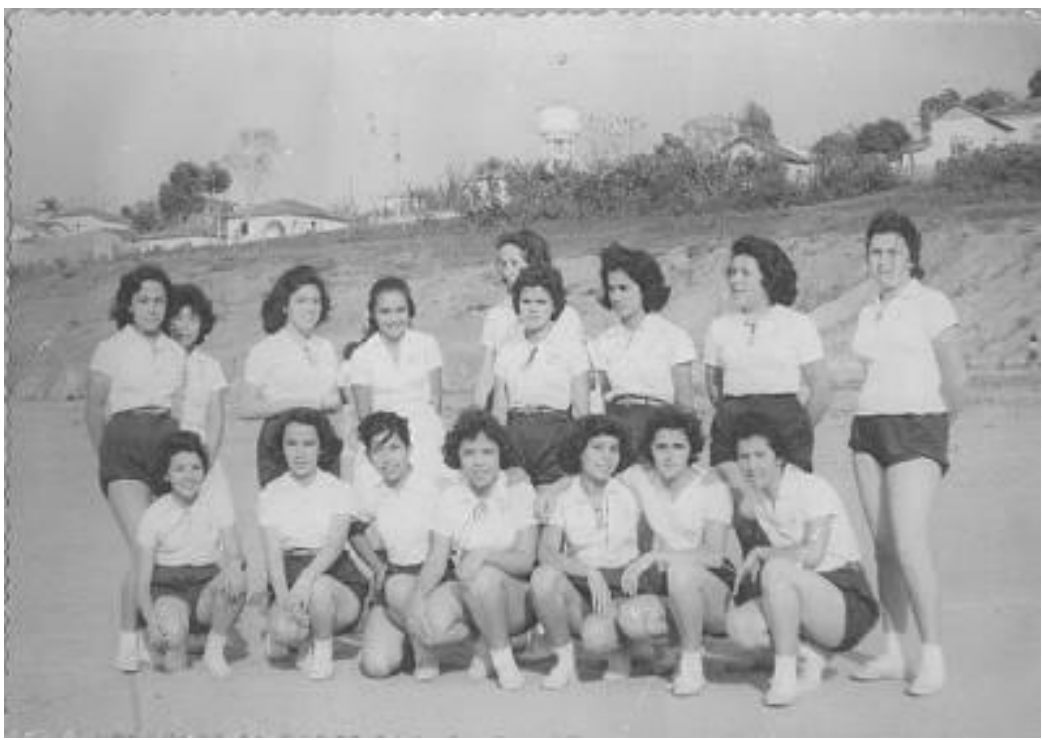

Figura 04 - Alunas uniformizadas para aulas de ginástica

Fonte: E. E. EF. M. Vereador Odilon Batista Jordão

O pátio escolar, durante os recreios era local de encontro, do lanche e constituía se no único lugar onde os alunos podiam descontrair-se e movimentar-se, apesar da constante vigilância da inspetora Cecília e muitas vezes da secretária Alice. Os recreios eram movimentados com brincadeiras de roda, corda, "pula-sela", "pega-pega" e longas conversas.

O pátio além de ser um espaço de descontração, também era local de apresentações, principalmente atividades de canto orféon, porém a maioria delas era restrita aos alunos e autoridades. Anualmente aconteciam poucas apresentações nesse espaço abertas a comunidade.

Os alunos do Ginásio Estadual de Pilar do Sul participavam da vida da cidade auxiliando na organização de festas, manifestações e atividades cívicas como Sete de Setembro e o aniversário de emancipação política de Pilar do Sul

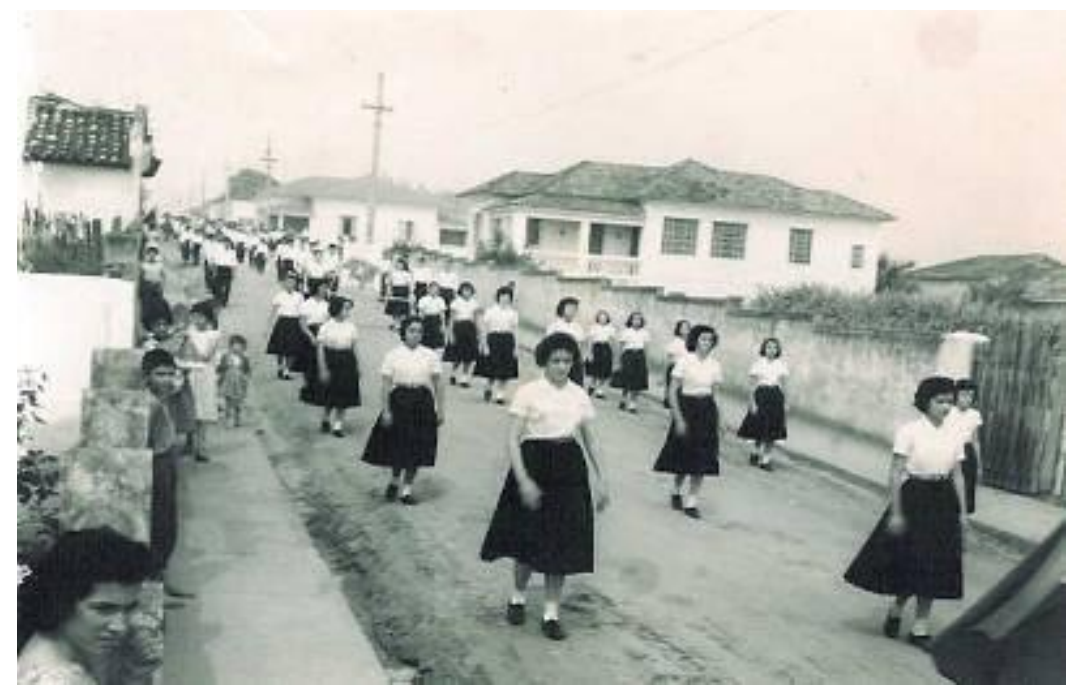

Figura 05: atividade cívica - 07 de Setembro

Fonte: E. E. EF. M. Vereador Odilon Batista Jordão 
A prática dos alunos participarem de eventos da cidade, principalmente cívicos, era considerada importante para a formação de cada aluno e também uma forma de demonstrar a importância dessa instituição para formação da população.

A relação entre o interno e externo era estabelecida pelo edifício do Ginásio Estadual de Pilar do Sul. Uma relação dialética, entre o espaço escolar com seus espaços demarcados, suas funções especificas, disciplinadora e a rua. Uma relação contraditória de um edifício que propõe um desenho disciplinador voltado para o interior e ao mesmo tempo sem muros que impedissem o elo com a rua e contemplamento do desenho do seu prédio pela população local.

\section{Considerações Finais}

Neste momento é importante reafirmar que essa é uma pesquisa em andamento, que faz parte de uma investigação mais ampla e destacar as dificuldades de funcionamento do Ginásio Estadual de Pilar do Sul devido a falta de materiais didáticos apropriados, mesmo após a inauguração do seu edifício.

O Ginásio Estadual de Pilar do Sul possuía um edifício de acordo com os ideais pedagógicos dominantes da época, onde valorizava a formação integral do aluno pautada no civismo e na racionalidade científica com uma disciplina rígida, onde o poder estava centralizado na figura principalmente do diretor e do corpo docente.

O edifico do Ginásio Estadual de Pilar do Sul possuía um desenho modesto, com linhas simples, comparado a edificações de outros lugares e tempos, mas para os "pilarense" o prédio do Ginásio Estadual de Pilar do Sul, simbolizava o progresso e a grandeza do povo. A maior construção na cidade por muitos anos.

Um espaço que servia como local do saber, mas também historicamente mantém a função simbólica e imaginaria de muitos que deixaram dias de suas vidas nos corredores do Ginásio Escolar de Pilar do Sul.

\section{Referências}

BEISIEGEL, Celso de Rui. Estado e educação popular. São Paulo: Pioneira, 1974.

A reforma e a qualidade do ensino. In NAGLE: Educação brasileira questões da atualidade. SPEDART, 1976.

BENCOSTTA, Albino; LEVY, Marcus (org). História da educação, arquitetura e espaço escolar. São Paulo: Cortez, 2005.

FARIA FILHO, Luciano Mendes de. Dos pardieiros aos palácios: cultura escolar e urbana em Belo Horizonte na Primeira Republica. Passo Fundo: UPF, 2000.

LE GOFF, Jacques. Documento/Monumento. In: Historia e memória. Campinas, SP: Ed. UNICAMP, 1990. 
SPOSITO, Marília Pontes. O povo vai à escola: a luta popular pela expansão do ensino público em São Paulo. São Paulo: Loyola, 1984.

SOUZA, Rosa Fátima de. Templos de civilização: a implantação da escola primaria graduada no Estado de São Paulo: (1890-1910). - São Paulo: Fundação Editora da UNESP, 1998.

TOMPSOM, Edward P. Tempo, disciplina de trabalho e o capitalismo industrial. In: Costumes em comum: estudos sobre a cultura popular tradicional. São Paulo: Companhia das letras, 1998, p. 267-304.

THOMPSON, Paul. A voz do Passado: historia oral - Trad. Lolio Lourenço de Oliveira. Rio de Janeiro: Paz e Terra, 1992.

VIDAL, Diana Gonçalves. Cultura e práticas escolares: a escola como objeto de pesquisa. In Cultura escolares. Estudo sobre práticas de leitura e escrita na escola pública primária (Brasil e França, Final do século XIX. Campinas, SP: Autores Associados, 2005

FRAGO VINÃO, Antonio. Por una historia de la cultura escolar, enfoques, cuestiones, fuentes. In: FERNANDEZ, Celso Almuniña et al. Cultura y Civilizações. Valladolid: Secretariado de Publicaciones e intercambio Científico, Universidad de Valladolid, 1998. p. $167-183$

Antonio. Sistema educativo, culturas escolares y reformas: continuidad y cambios. Madri: Morata, 2003

Notas:

\footnotetext{
${ }^{1}$ Silvia Diniz é moradora de Pilar do Sul e foi aluna do $1^{\mathrm{a}}$ turma do Ginásio Estadual de Pilar do Sul.

${ }^{2}$ Salão paroquial pertencente à igreja católica local.

${ }^{3}$ Alice Diniz de Carvalho, primeira secretária do Ginásio Estadual de Pilar do Sul, onde trabalhou por trinta anos.

${ }^{4}$ Dona Cecília Pereira Carvalho de Oliveira, foi a primeira inspetora de alunos do Ginásio Estadual de Pilar do Sul, trabalhou nessa instituição, trinta anos e nove meses.
} 